\title{
Participative leadership in the management process of nightshift nursing ${ }^{1}$
}

\author{
Diovane Ghignatti da Costa $^{2}$
}

Clarice Maria Dall'Agnol ${ }^{3}$

This is a qualitative, exploratory, descriptive study, aiming to identify the perceptions of nurses regarding the leadership process and to analyze how this process takes place on the nightshift. Data collection was performed through the Focus Groups Technique, with 13 nightshift nurses of a public teaching hospital. Two categories that resulted from the thematic analysis are the focus of this article: the context of nightshift nursing work and leadership from the perception of the nightshift nurses. Teamwork is an important condition to vitalize the participatory perspective of the leadership process, given the necessary relationship of support and integration, above all in the nightshift nursing work. This exercise challenges the nurse in the solidification of a culture that promotes spaces for reflection regarding the work, integrating leadership with a learning process that is constituted through constructive bonds between the workers.

Descriptors: Leadership; Nursing, Night Work; Group Processes; Focus Groups.

\footnotetext{
1 Paper extracted from Master's Thesis "Liderança no processo grupal: instrumento para o trabalho noturno em enfermagem", presented to Escola de Enfermagem, Universidade Federal do Rio Grande do Sul, Porto Alegre, RS, Brazil.

2 RN, M.Sc. in Nursing, Hospital de Clínicas de Porto Alegre, RS, Brazil. E-mail: dgcosta@hcpa.ufrgs.br.

${ }^{3}$ RN, Ph.D. in Nursing, Associate Professor, Escola de Enfermagem, Universidade Federal do Rio Grande do Sul, Porto Alegre, RS, Brazil. E-mail: clarice@adufrgs.ufrgs.br.
}

Corresponding Author: Diovane Ghignatti da Costa Av. Ramiro Barcelos, 2350, Sala 500 Bairro: Santa Cecília CEP: 90035-903, Porto Alegre, RS, Brasil E-mail: dgcosta@hcpa.ufrgs.br 


\section{Liderança participativa no processo gerencial do trabalho noturno em enfermagem}

Trata-se de pesquisa qualitativa, exploratória, descritiva, objetivando identificar as percepções dos enfermeiros sobre o processo de liderança, e analisar como transcorre esse processo no turno noturno. A coleta de dados foi realizada por meio da Técnica de Grupos Focais, com 13 enfermeiras que trabalham nesse turno, em um hospital público de ensino. Duas categorias que resultaram da análise temática são foco deste artigo: o contexto do trabalho noturno em enfermagem, e a liderança na percepção das enfermeiras do noturno. $O$ trabalho em equipe é importante condição para vitalizar a perspectiva participativa do processo de liderança, haja vista a necessária relação de apoio e integração, sobretudo no trabalho noturno de enfermagem. Esse exercício lança um desafio ao enfermeiro, caracterizado como uma busca de concretização de uma cultura que promova espaços de reflexão acerca do trabalho, integrando a liderança a um processo de aprendizagem que se constitui mediante vínculos construtivos entre os trabalhadores.

Descritores: Liderança; Enfermagem; Trabalho Noturno; Processos Grupais; Grupos Focais.

\section{Liderazgo participativo en el proceso de gestión del trabajo nocturno de enfermería}

Se trata de investigación cualitativa, exploratoria y descriptiva, con los objetivos de identificar las percepciones de los enfermeros sobre el proceso de liderazgo y analizar como transcurre ese proceso en el turno nocturno. La recolección de datos fue realizada por medio de la Técnica de Grupos Focales, con 13 enfermeras que trabajaban en ese turno en un hospital público de enseñanza. Dos categorías que resultaron del análisis temático son enfoque de este artículo: contexto del trabajo nocturno en enfermería y el liderazgo en la percepción de las enfermeras del turno nocturno. El trabajo en equipo es una importante condición para vitalizar la perspectiva participativa del proceso de liderazgo, considerando la necesaria relación de apoyo e integración, sobre todo en el trabajo nocturno de enfermería. Ese ejercicio lanza un desafío al enfermero, en la concretización de una cultura que promueva espacios de reflexión acerca del trabajo, integrando el liderazgo a un proceso de aprendizaje que se constituye mediante vínculos constructivos entre los trabajadores.

Descriptores: Liderazgo; Enfermería; Trabajo Nocturno; Procesos de Grupo; Grupos Focales.

\section{Introduction}

Leadership as a management instrument for the practice of nursing care has been evidenced in studies $^{(1-2)}$ that have investigated the subject, which indicate the influence of models predominantly associated with Scientific and Classical Theories of Administration. The tight control that emanates from such models is present in the quotidian nursing work, even with the new management proposals guided by teamwork and participatory processes ${ }^{(3-7)}$. The theories of leadership, in turn, have been feeding back in the evolution of these scientific principles of administration. Therefore, while the starting point was very focused on the characteristics and the behavior of the leader, subsequent studies have contemplated variables related to the situation and to the interactions between subjects inserted in an organizational culture ${ }^{(8)}$. It is noteworthy that the interactive focus has marked some contemporary leadership approaches, which valorize 
participatory processes between the workers and consider leadership a group process, through the mutual influences of the subjects among themselves, directed towards common defined purposes ${ }^{(9-11)}$. However, it is important to highlight that the nurse is sometimes unable to mediate group situations and this results in difficulties in the exercise of leadership, as has been indicated in the literature ${ }^{(2,12)}$. From this perspective, it becomes essential to develop, in the process of nursing work, skills that support coping with these difficulties in a constructive way. Some authors stress that flexibility and commitment, guided by ethics and values, are necessary to exercise leadership in a culture that seeks support actions and mutual collaboration among the nursing team ${ }^{(13-15)}$.

The conceptual framework adopted for this study is the meaning of leadership as a process that valorizes the potential resources of the work team and the actions of sharing and of complementarity that are either included or enjoyed by the group, exercising them in their quotidian. To this end, it is guided by principles derived from theoretical models that are inscribed in the participatory aspects of leadership and that promote the emancipatory condition of the subjects. Participative leadership postulates principles that take into consideration, among other aspects, the values of those involved, the working conditions and the environment, configuring questions that reflect the organizational culture and that are centered on cooperation and relationships of trust ${ }^{(8,11)}$. The leadership process, from this perspective, therefore, favors the establishment of constructive bonds between the people and integrates leadership into a learning process, which takes place in the experiences of each one and in the sharing with the others ${ }^{(14,16)}$. In the theory of PichonRivière(17), this dynamic happens in the group process, through the action of the verticality of the subject and of the horizontality that takes place in the group, i.e. at the intersections between the life stories of each of the members, which are shared, objectifying a task that constitutes the purpose of the group.

The systematic knowledge on the theme shows/ indicates/demonstrates that transformational leadership composes one of the approaches that converge toward participatory models and considers vision and motivation, resulting from strenuous participation, involvement of the people, cooperation and responsibility, which are fundamental to the exercise of leadership ${ }^{(8,11)}$. However, it is noteworthy that these contemporary leadership approaches with a participatory focus do not contradict the precursor theories of leadership that ensure the quotidian operations of the work through transactional leadership skills, such as knowledge of the processes, routines and techniques ${ }^{(8)}$.

By focusing the discussion on the specific scenario of nightshift work, it is emphasized that the relational dimension is highlighted as an indispensable competence for the exercise of leadership ${ }^{(13,18)}$. In addition, tiredness and fatigue are challenging elements for the care and, considering the presence of these factors, the nurse must presuppose experience and safety in the decision making, through technical knowledge, sensitivity and relational competence ${ }^{(18-19)}$.

These reflections are an invitation to (re)think about the leadership models that have provided foundations for the work practices and about the multiplicity of questions intertwined with the exercise of leadership, considering them as resulting from the process of interaction between the subjects. Therefore, it is considered that nurses have an important role in triggering a process that valorizes the participation of all the team members as a possible instrument to articulate new practices, bringing repercussions both for the teams, and for the users of the healthcare system. Thus, the aim of this study was to identify the perceptions of the nurses regarding the leadership process and to analyze how this process takes place on the nightshift.

\section{Methodological framework}

This was an exploratory, descriptive study, with a qualitative approach. The study participants were 13 nurses of the nightshift of a public, general, university hospital of the capital of Rio Grande do Sul. The inclusion criteria consisted of being a nurse of the nightshift in care activities of the hospital of study, interested in discussing the theme and with the time available to attend the meetings. The exclusion criteria consisted of the nurses being on leave due to vacation, sickness or other scheduled absences such as leave to participate in a congress.

The data were collected during September and October 2009 through the Focus Groups Technique. This technique allows for discussion and reflection on a theme through group sessions, in order to discover the 'to do' of the people from the group interaction(20). Four weekly meetings were carried out, each with a duration of 1 hour and 30 minutes, audio recorded, in a location of easy access for the participants, which provided privacy, comfort and an internal arrangement that facilitated 
dialogue and face-to-face contact. Considering these requirements, the meetings occurred in a hospital room reserved for this purpose, in the afternoon, due to the preference of the participants. The researcher, as the moderator of the discussions, asked group triggering questions in order to stimulate the discussions based on the research aims, such as: "Tell us about the exercise of leadership in your work". "What leadership practices have been adopted by the nurses of the nightshift? Give examples".

After verbatim transcription, performed by the researcher, the information was submitted to thematic analysis(21), which was divided into three steps: the preanalysis consisted of the free-floating reading of the transcribed material and the constitution of the corpus of analysis, valorizing the exploratory procedures. Next, a classification operation was performed, which aimed to obtain the relevant points or core comprehension of the text, which were grouped, defining the empirical categories through the classification and aggregation of the data. In the final step, the treatment and interpretation of the results obtained was carried out, based on the theoretical framework of the study.

Regarding the ethical aspects, the study complied with Resolution 196/96 of the National Health Council(22), having obtained a favorable decision under number 09162 of the Research Ethics Committee located in the study location. Data collection only began after the individual signing of the Terms of Free Prior Informed Consent. Among other details, the subjects were guaranteed exemption from influences that could interfere with their employment contract at the Hospital and also preservation of the confidentiality of the information, assigning them the codes P1 (Participant 1), P2 (Participant 2) successively, in the dissemination of the results.

\section{Results and Discussion}

The analysis of the focus group discussions highlighted two categories regarding the perceptions of the nurses about the leadership process and how this process takes place on the nightshift.

\section{The context of nightshift nursing work}

Some aspects that influence the way the leadership process takes place in the nightshift work quotidian received emphasis in the discussions. In this sense, there were signs of factors that dynamize or hamper the exercise of leadership, related to the organization of the work, as highlighted in the following expression: [...] I used the word organization as leadership, because when you have determined a way to work and they see that this functions, in a more organized way [...] you manage to encourage the qualities of an employee [...]. When you see that organization is effective in the entire group, they can manage to work and change their attitude, despite sometimes having a profile slightly difficult to work with, they will comply and you see that the work changes in the group (P4). Source: Focus Group, Meeting 2.

In this way, the organization of the work was an issue that permeated the discussions throughout the four focus group meetings, unfolding in themes that have implications in the way that the nursing team is structured, it relates to and is positioned opposite the singular reality in which the work is developed on the nightshift.

The participants highlighted the importance of having professional experience prior to working on the nightshift because the nurse assumes activities related to the care management that are shared in the dayshift by the management team that is present. Thus, knowing the connections of the area in which they act with the other areas of the hospital, through their experience and knowledge of the institutional work processes, facilitates decision making, according to the following statement: [...] to have this experience of the dayshift, to see how the hospital functions during the day, facilitated working at night, in the safety of the decisions to be taken at night [.. ] (P3). Source: Focus Group, Meeting 1.

It appears that the experience of monitoring the dynamics of work during the dayshift strengthens the nurse in the situations that require immediate solutions, on their shift, seeking continuity of the processes and the potential of resolvability throughout the 24 hours of the day. Furthermore, it must be considered that the professional experience is described by some authors as a condition that can encourage a participatory attitude regarding the work process $(7,13,18)$, necessary for those who share the quotidian situations with those involved, seeking to problematize the decision-making process, in order to make better choices ${ }^{(5)}$.

At different moments in the focus group discussions, the nurses talked about the nightshift working environment, recognizing it as more relaxed compared to the other shifts, as illustrated by the following statement: [...] you have more time for administration, to plan the care. I think it is a much more relaxed shift, [...] this also contributes to the quality of your work (P9). Source: Focus Group, Meeting 1. 
This confirms other findings ${ }^{(19)}$ which highlight the peculiar ambience of the nightshift as an advantage. In the discussion, the group explained that the period of twelve hours of work, relative to each shift, favors communication with teams, family members and patients and that the reduced circulation of people makes the atmosphere more relaxed, conducive to the care planning, which allows the group to (re)think about their relationships and to strengthen bonds.

However, there were discussions regarding the tiredness and fatigue of the workers of the nightshift, a condition that hinders the work of the team. The theme emerged in the discussion, when one of the nurses reported how she acted against attitudes that she considered inadequate, related to the fatigue of the team. When asked whether it was possible to discuss this in the team, the following statement emerged: I have not yet reached this point, when something happens I have to point it out immediately, I ask them: what would you do in my place? [...] on the day of the shift I don't arrange anything, I need to sleep. [...] I cannot come to the shift tired (P7). Source: Focus Group, Meeting 3.

The problems related to tiredness and fatigue reflects the fragile condition of the nursing team to cope with difficulties that involve subjectivities emerging from the work, which refers back to the inability of the nurse to deal with group situations, a condition demonstrated by studies ${ }^{(12,18)}$ and that has repercussions in the work.

Another issue relates to the organization of the hospital nightshift work with respect to the peculiar conditions of logistical support, of both care and support services: [...] when I come to work during the day, I hardly ever make the same decisions I make alone at night, because the supervisor is present. It is not due to accommodation, but a question of exchanging ideas with the supervisor, about what I think. At night as I do not have this, we end up discussing things between us [...] (P1). Source: Focus Group, Meeting 3.

This configuration has been reported both in national studies ${ }^{(18-19)}$ and in the international(13) context, having repercussions in the decision-making process of the nursing team. The articulation of the demands arising from the different organization of the nightshifts makes the possibility of exchange between the team members transparent, because the situation is decided and discussed among those that are present, given the absence of the supervisors on this work shift.

\section{Leadership from the perception of the nightshift nurses}

Throughout the discussions, concepts regarding the leadership process on the night shift were expressed by the nurses, who mentioned leadership attributes, qualities and practices that they consider relevant in the work quotidian. The group pointed out that the valorization of multiple qualities in the team enriches everyone and has a positive impact on the work of the team. The following exemplifies this issue: I think it's a way to strengthen ourselves as a group, because you cannot be totally explosive, you cannot be too soft. So, I find this mix of personalities very interesting. [...] because of this, I think that in leadership we have to have flexibility (P4). Source: Focus Group, Meeting 2.

Flexibility therefore boosts the sharing of ideas in order to develop and qualify the group performance. This would be an initial route to establishing professional relationships guided by participatory and ethical attitudes, identified as a necessity to consolidate a new model of organizational culture ${ }^{(11,14,16)}$. However, for actions to be implemented through participatory processes, it is necessary to cultivate the commitment of everyone with the work. The following excerpt illustrates this idea discussed in the group: [...] When you have leadership that is more free, uncommitted, the group also becomes disengaged. Now, when you have leadership that is organized, that seeks responsibility, that seeks to work together [...], we see that the group is shaped according to the leadership (P13). Focus Group, Meeting 2.

Through this reflection, it can be perceived that the commitment of the team with the work, or the lack of this, follows the logic of those who exercise the leadership, which serves as a model for the others. In nursing, the articulating characteristic of the nurse as an active participant in the health care team has already been established $(2,4,7,13)$. Because of this prominent position, nurses are expected to be leadership subjects and to promote ways to encourage the leadership potential of the other workers. When this is established through constructive bonds, it is reflected in the desire to belong to the same team, to produce in a joint manner, to contribute. This perspective does not ignore leadership as an individual process, but focuses on the relationships that result from individual and social abilities $^{(10,13)}$, producing learning processes among those who share them.

In the course of the discussions, the need to invest in self-reflection, producing questions that may prompt professionals to reassess their attitudes at work was talked about. The competence of the work was also emphasized, not only in relation to technical knowledge, but also to the articulations performed in the day-today of work. The nurses also highlighted the importance 
of the moments of exchange, which was revealed in simple actions, such as giving attention to co-workers, which had significant repercussions in the relationships established between them. For this, communication skills, confidence, respect and proactivity are needed, as well as the establishment of bonds guided by ethical and human values, which produce, in turn, resonance in the care and the motivation of the workers. In the group, it was seen that the articulation of the diverse factors involved in the exercise of leadership makes its practice complicated in the work quotidian. The following dialogue presents a synthesis of these ideas: The exercise of leadership involves a series of qualities such as: responsibility, impartiality, flexibility, tolerance, confidence, competence, stability, management, ethics, organization, respect, empathy, humility and justice. The leader is the person who gives everything and a bit more for the institution, who explains things to the group, who is proactive, who everyone wants to be in their team, because they seek to resolve things. [...] have vision and the common sense to evaluate the situation. It is not easy because it involves a set of things (P9). It's all that and a little bit more (P11). Wonder Woman (P8)! I would include in this list the training, because I think we must have these skills, but you have to study for this [...] (P9). Source: Focus Group, Meeting 4.

The dialogue highlights the possibility that leadership skills are subject to being gained and learned. However, the group reasoned that leadership is not an easy exercise, given the multifactorial dimension that involves the process, which relates to the individual, relational and organizational contexts. This difficulty has been linked to the dynamicity necessary to acquire leadership skills that can cope with the constant changes that take place in the world ${ }^{(8)}$. For these multifactorial characteristics, it was considered that leadership is constituted from relationships of complementarity, since the "wonder woman" mentioned in the dialogue does not encompass alone many attributes that could fulfill the needs of the current scenario of the healthcare services. The attributes mentioned, such as courage, confidence, ethics and respect indicate a pathway for achieving this vision of complementarity of the nursing team.

Throughout the discussions in the focus groups, two opposing visions of leadership emerged in the moments when the situations experienced by the team were being discussed. One dichotomized the subjects into leaders and led, producing working relationships that have strengthened the hegemonic model of care production. This model is inspired by a practice that valorizes the social distance between the subjects in order to potentialize the role of the leader ${ }^{(9)}$, by means of relationships based on control ${ }^{(14)}$. The other brings together leadership with the concept of learning, as a way of developing competence in the group performance(16). Thus, it can be seen that different models of leadership influence the nursing practices. The following statements indicate these different visions: This story of leadership, you must be really flexible. You are the leader, aren't you? If you are the supervisor. Should I put myself lower? (P12) Source: Focus Group, Meeting 2. Maybe on this occasion the colleague [...] was quiet, she thought: "if I argued, [...] it would not solve anything now". However, at a later time, they can change their minds and discuss the situation. Because you can't remain neutral, withdraw yourself, be in a limbo (P8). Source: Focus Group, Meeting 2.

In the first statement, it appears that the leadership was naturally associated with the figure of the nurse. However, such a statement permeates a dichotomizing idea, which advocates the distancing between the subjects, displayed by positions, above or below, that the workers occupy in the network of relationships and which are presented through the power established by the hierarchy. In turn, the following statement highlights a practice that invites reflection and dialogue, focusing on the need for assertive positioning when faced with the situations that the team encounters in the day-to-day of work. The difficulty in making decisions, in positioning themselves in the face of polemic issues which the healthcare workers encounter, can generate distress in the relationships, making the group process difficult, which provokes distancing between the people ${ }^{(6)}$.

Other statements revealed a productive environment to exercise leadership, in light of the participatory perspective, in that different members of the nursing staff highlighted situations that require intervention: [...] they [the nurses] brought me to this situation, to see that when you get to a point that is bad for the group, the group mobilizes to try to solve the problems [...] (P8). Source: Focus Group, Meeting 2.

As stated, when perceiving a problematic situation, the team signals the need for engagement, through dialogue and jointly searching for a solution. Solutions do not always emerge immediately from these engagements, however, this practice of dialogue, as well as the decentralization of the decision-making process promote trust between people and develop ideas, facilitating the construction of viable alternatives for each specific context. Along with this attitude, the relationship between the team members, based on warmth and trust, makes the relationship and the 
intervention in conflictive situations present in the quotidian of collective working even easier(4).

In these counterpoints that situate the leadership practices between two seemingly contradictory poles of the management team, one that focuses on dialogue, on the supervision that supports the work and strengthens the relationship and the other in which the practices are based on the control and the demands, emerged the stereotypes of being "being a good girl" or "being a witch". In deepening the discussion of such contradictions, the group was faced with a moment of insight, indicating a course for the dissolution of these stereotypes, as revealed in the following statements: [...] The measures that you adopt, you do not adopt alone, because once an opinion is given by someone, they commit themselves. This somewhat dilutes that power of the witch, because everyone is together in the caldron, everyone puts in a pinch of salt, we're together in that decision (P8). I think we need to stop and think a little, why are we using this jargon of the witch? We are stigmatizing a good leader [...]! One that follows the rules of the hospital, one that does everything they can and more, one that solves the problems, that explains things to the group, that everyone wants to work with [...] (P2). Source: Focus Group, Meeting 3.

It is inferred from the discussion that procedures guided by rules and standards are valorized in the work, those which reflect the heritage of models in which the foundations arise from the classical approaches of administration. Furthermore, by adding to this foundation, which organizes and ensures good results in the care, an approach that valorizes the interaction among the team, it promotes new possibilities to work from collective concepts. This group movement has triggered the demystification of the demand, which has resulted in a meaning that guarantees the performance of the work within the guiding principles, such as protocols and care routines, but considers other dimensions when performed in a way that valorizes the interrelationship between the subjects involved in the process and in its unfolding, which relates to the bonds constructed. The deepening of the debate regarding this issue sought to comprehend the necessary connection that should be made between transactional and transformational skills of leadership.

\section{Final considerations}

The results indicated some factors that dynamize the exercise of leadership, by favoring the investment in communication and interaction among the workers, such as motivation related to the nightshift, the relaxed environment and the knowledge of the nurses regarding the work and its connections with the different sectors of the hospital.

However, it was also indicated by the group that tiredness and fatigue, which arise from the work activities in the course of the nightshift, have affected the performance of the workers and the interpersonal relationships. This circumstance makes weaknesses apparent in the group process of the nightshift nursing teams, indicating some conflicts in the practice of leadership, resulting from a lack of strategies for the team to cope with the situation.

The nurses recognize that leadership involves a series of attributes and qualities that underlie the individual and relational context, and also factors related to the organization of the work that reflect on how the team relates and articulates itself faced with the demands. The condition of linking the individual, relational and organizational dimensions required for the exercise of leadership makes its practice complicated, which explains the difficulty faced in the quotidian of nursing work.

In the reflections of the group, conceptions of leadership emerged that suggested the influence of different models, revealing apparently antagonistic and contradictory principles in the management of the work. Taking these models as a basis, the exercise of leadership challenges the nurse team leader, in the solidification of a culture that provides spaces for reflection about the work, with a view toward the necessary interventions. In this joint movement, the team can define actions relevant to the reality of work, which associates leadership with learning, by connecting transactional and transformational leadership skills, thus strengthening new management processes.

Therefore, the involvement of the nursing professionals in issues related to teamwork and group dynamics is an important condition to vitalize the participatory perspective of the leadership process, given the necessary relationship of support and integration of the team, above all in the context of nightshift nursing work.

\section{References}

1. Balsanelli AP, Cunha ICKO. Liderança no contexto da enfermagem. Rev Esc Enferm USP. 2006;40(1):117-22. 2. Lanzoni GMM, Meirelles BHS. Liderança do enfermeiro: uma revisão integrativa da literatura. Rev. Latino-Am. Enfermagem. 2011;19(3):651-8. 
3. Fernandes MS, Spagnol CA, Trevizan MA, Hayashida M. A conduta gerencial da enfermeira: um estudo fundamentado nas teorias gerais da administração. Rev. Latino-Am. Enfermagem. 2003;11(2):161-7.

4. Fortuna CM, Mishima SM, Matumoto S, Pereira MJB. O trabalho de equipe no programa de saúde da família: reflexões a partir de conceitos do processo grupal e de grupos operativos. Rev. Latino-Am. Enfermagem. 2005;13(2):262-8.

5. Cardoso ASF; Mielke FR; Riboldi CO; Soares NV; Olswchowski A; Dall'Agnol CM. Coordenação de grupos na enfermagem - reflexões à luz de Pichon-Rivière. Rev Min Enferm. 2009;13(2):288-92.

6. Grando MK, Dall'Agnol CM. Desafios do processo grupal em reuniões de equipe da estratégia saúde da família. Esc Anna Nery. 2010;14(3):504-10.

7. Moura GMSS, Magalhaes AMM, Dall'Agnol CM, Juchem BC, Marona DS. Leadership in nursing: analysis of the process of choosing the heads. Rev. Latino-Am. Enfermagem. 2010;18(6):1099-106.

8. Marquis B, Huston C. Administração e liderança em enfermagem: teoria e aplicação. 6.ed. Porto Alegre: Artes Médicas; 2010. 671 p.

9. Motta PR. Gestão Contemporânea: a ciência e a arte de ser dirigente. 15.ed. Rio de Janeiro: Record; 2004. $256 \mathrm{p}$.

10. Rivera FJU, Artmann E. A liderança como intersubjetividade lingüística. Interface - Comunic, Saude, Educ. 2006;10(20):411-26.

11. Bamford-Wade A, Moss C. Transformational leadership and shared governance: an action study. J Nurs Manage. 2010;18(7):815-21.

12. Simões ALA, Fávero N. O desafio da liderança para o enfermeiro. Rev. Latino-Am. Enfermagem. 2003;11(5):567-73.

13. Gustafsson C, Fagerberg I, Asp M. Supportive leadership in Swedish community night nursing. J Nurs Manag. 2010;18(7):822-31.

14. Bondas T. Nursing leadership from the perspective of clinical group supervision: a paradoxical practice. J Nurs Manage. 2010;18(4):477-86.

15. Vendemiatti M, Siqueira ES, Filardi F, Binotto E, Simioni FJ. Conflito na gestão hospitalar: o papel da liderança. Ciênc Saúde Colet. 2010;15 Supl 1:1301-14. 16. Gayotto MLC, organizadora. Liderança II: aprenda a coordenar grupos. 2.ed. Petrópolis (RJ): Vozes; 2004. $239 \mathrm{p}$.

17 Pichon-Rivière E. O processo grupal. 7.ed. São Paulo: Martins Fontes; 2005. 286 p.
18. Moreira MC, Silva SCB. Práticas de liderança adotadas por enfermeiros no serviço noturno. Rev Enferm UERJ. 2007;15(2):183-9.

19. Silva RM, Beck CLC, Guido LA, Lautert L, Tavares JP, Prestes FC, et al. Night shift pros and cons in nursing: qualitative study. Online Braz J Nurs [periódico na Internet]. 2009 [acesso 25 out 2010]; 8(2): [cerca de 16p]. Disponível em: http:// www.objnursing.uff.br/index.php/nursing/article/ view/j.1676-4285.2009.2346/html_8

20. Dall'Agnol CM, Ciampone MHT. Grupos focais como estratégia metodológica em pesquisa na enfermagem. Rev Gaúcha Enferm. 1999;20(1):5-25.

21. Minayo MCS. O desafio do conhecimento: pesquisa qualitativa em saúde. 9.ed. São Paulo: Hucitec-Abrasco; 2006. 406 p.

22. Ministério da Saúde (BR). Conselho Nacional de Ética em Pesquisa em Seres Humanos. Resolução n⿳0 196, de 10 de outubro de 1996: diretrizes e normas regulamentadoras de pesquisas envolvendo seres humanos [Internet]. [acesso 8 out 2010]. Disponível em: http://conselho.saude.gov.br/comissao/conep/ resolucao.html.
Received: Mar. 16 2011 Accepted: Oct. $11^{\text {th }} 2011$ 